\title{
The Challenges of Implementing Information and Communications Technology (ICT) Based Online Learning in Chinese Independent High Schools (CIHS) in Malaysia
}

\author{
Mak Vee Vien ${ }^{1}$, Joanna Tan Tjin $\mathrm{Ai}^{1}{ }^{\&}$ Cheah Kok Sung ${ }^{1}$ \\ ${ }^{1}$ Faculty of Arts and Social Science, Universiti Tunku Abdul Rahman, Malaysia \\ Correspondence: Mak Vee Vien, Faculty of Arts and Social Science, Universiti Tunku Abdul Rahman, Malaysia.
}

Received: May 1, 2019

doi:10.5430/rwe.v10n2p117
Accepted: June 1, 2019

Online Published: July 9, 2019

URL: https://doi.org/10.5430/rwe.v10n2p117

\begin{abstract}
The use of ICT in the teaching and learning process is one of the most discussed topics in education for the past twenty years. It has, particularly, put education in Chinese Independent High Schools (CIHS) in Malaysia into a more challenging place due to their distinctions that revolve around self-funding, medium of instruction and syllabus. Past studies have indicated that most teachers had positive attitudes towards ICT integration in education. However, there are also some barriers that have prevented them from fully utilizing ICT in schools. This study focuses on investigating teachers' perceptions and challenges faced while using ICT based online learning in the process of teaching and learning. A total of 180 questionnaires were randomly distributed to CIHS English teachers in West Malaysia. The questionnaire was adapted from Qasem \& Viswanathappa (2016) and Salehi \& Salehi (2012). A pilot study was also done to ensure the reliability and validity of the instruments. Besides using descriptive analysis, t-Test and One-Way ANOVA were also used to analyse the data. About two-third of the respondents in this study had the awareness towards the use of technology in education and perceived positively towards ICT in the teaching and learning process. The major challenges faced while using ICT included unstable internet connection, lack of training, lack of support from the school, lack of time. In order to ensure a more successful implementation of ICT in education, appropriate training on the usage of ICT in teaching should be provided. Apart from this, adequate ICT resources must be made available for teachers. This study might be significant to the educators, researchers and school managements to help develop useful guidelines to assist the teachers in overcoming the challenges of using ICT in teaching and learning.
\end{abstract}

Keywords: Information and Communications Technology (ICT), online learning, Virtual Learning Environment (VLE), perceptions, challenges

\section{Introduction}

According to the Malaysia Educational Blueprint (2015-2025), there are 3.035 billions of internet users in the world. This helps to promote online learning and has significantly enhanced the implementation of Information and Communication Technology (ICT) in education. ICT, a scientific tool that offers effective teaching and learning process for teachers and students, is very much connected to our every day's life (Aktaruzzaman, Shamim \& Clement, 2011). The use of ICT helps to improve the interaction between teachers and students (Meenakshi, 2013; Moussa, 2018). A past study also mentioned that the use of ICT has grown rapidly and it enhances the potential of teaching and learning in different stages (Yunus, et al., 2013).

For the past twenty years, the use of ICT in the teaching and learning process was one of the most discussed topics in education (Ghavifekr et al., 2014). The purpose of this study is to focus on the use of ICT based online learning among English teachers in Chinese Independent High Schools (CIHS) in West Malaysia. A study by Jayanthi and Kumar (2016) mentioned that it is important to learn English as English has become one of the most common languages used all over the world. In fact, English is a compulsory subject that students are required to learn as a second language during their primary and secondary levels in Malaysia (Hiew, 2012; Musa, Abdullahi \& Baba 2017). However, the use of ICT in English Language teaching and learning is still far from encouraging (Yunus, et al., 2013) because of the challenges faced by teachers. 
CIHS were initiated by the Chinese community (Tan \& Teoh, 2014) since 1957 . They are affiliated to the United Chinese School Committees' Association (UCSCA), also known as Dong Zong, as well as the United Chinese School Teachers' Association (UCSTA) or Jiao Zong (Tan \& Teoh, 2014). Until 2014, a total of 60 CIHS were set up in Malaysia (Low, 2015). The ICT integration in schools has significantly put CIHS's education in Malaysia into a more challenging place due to their self-funding status, the medium of instruction and the syllabus used. Despite that CIHS recognize the effectiveness of using ICT in teaching and learning process, CIHS are facing more challenges on the ICT integration compared to those government schools in Malaysia as they are considered as non-profit schools and they do not receive funding from the Malaysian government (Low, 2015). A study by Kumutha and Hamidah in 2014 stated the major challenges faced by English teachers in CIHS included insufficient ICT knowledge, inadequate internet coverage, bundles of heavy workload on the teachers and so on. Nonetheless, there were limitations in the study as it only focused on 12 English teachers in one single school (Kumutha \& Hamidah, 2014; Mujtaba \& Jamal 2018). Thus, this study intends to further investigate on English teachers' perception and the major challenges to ICT integration in CIHS in West Malaysia on a wider scope.

\subsection{Research Questions}

1) What is CIHS English teachers' perception on the implementation of ICT based online learning in West Malaysia?

(a) Does teachers' gender influence their perception on the implementation of ICT based online learning?

(b) Does teachers' teaching experience influence their perception on the implementation of ICT based online learning?

2) What are the challenges faced by English teachers in CIHS in West Malaysia on the implementation of ICT based online learning and teaching?

\section{Literature Review}

\subsection{The Use of ICT as A Teaching and Learning Tool in Education}

A past study by Yunus, Salehi and Chenzi (2012) which focused on the use of ICT in teaching English as a Second Language (ESL) writing class agreed that the technological way of learning allowed students to explore with Virtual Learning Environment (VLE). VLE has practically supported independent learning and encouraged students to learn through online (Baker \& Gossman, 2013). Students can improve their learning quality (Ghavifekr et al., 2014) if their teachers use ICT in the classroom. A past study by Malaysia's researchers concluded that most teachers had positive perception that ICT had in fact provided them benefits in their teaching with updated materials available on the internet (Ghavifekr \& Ibrahim, 2015). However, teachers' personal characteristics like their gender and teaching experience in education might influence their perception on ICT integration in schools (Buabeng-Andoh Charles, 2012). Teachers with more years of service generally belong to the older generation who preferred traditional way of teaching over the advance technological way. In a nutshell, although teachers have positive attitudes to use ICT in classroom, however, some internal and external challenges might still discourage them to teach by using ICT (Md. Shah \& L. Empungan, 2015; Murshed, 2018).

\subsection{The Challenges of Using ICT as A Teaching and Learning Tool in Education}

A study by Gryzelius (2015) with interview sessions found that generally teachers faced challenges like insufficient internet coverage, teachers' lack of interest and lack of trainings on ICT. A study by Raman and Halim Mohamed (2013) found that teachers in Secondary schools in Malaysia only used ICT tools for basic purposes such as preparing PowerPoint slides and searching online information but students were not actually given the opportunity to explore the new technological way of learning. Another study has concluded that because of the bundle of workload, teachers had insufficient time to use ICT to prepare teaching materials (Tian \& Correos, 2014). Other reasons include schools not provide enough ICT resources and training programs for teachers (Tian \& Correos, 2014; Mwanja, Evusa \& Ndirangu 2018) and this has prevented them to adopt ICT in their lessons. This study aimed to investigate the major challenges to the use of ICT in schools and intend to recommend some useful guidelines to encourage the use of ICT in Malaysian education. 


\subsection{Conceptual Framework}

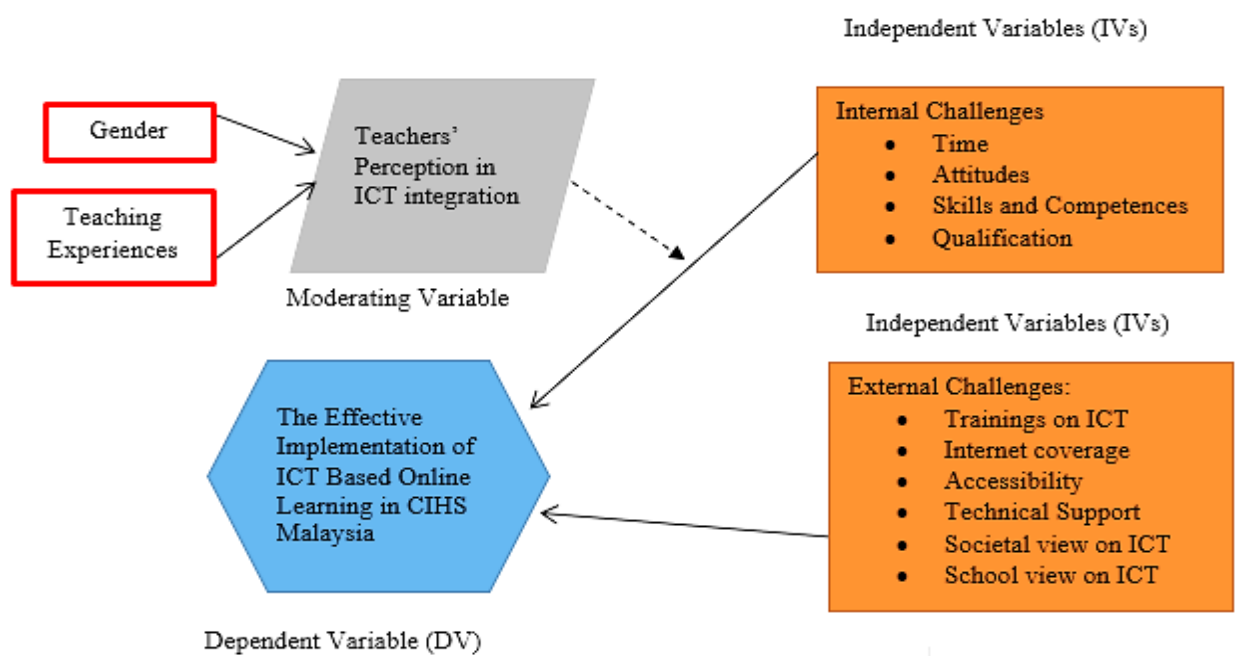

Figure 1. Conceptual framework

Figure 1 is the conceptual framework in this study. The effective implementation of ICT based online learning in CIHS Malaysia is the Dependent Variable (DV) while those internal and external challenges are known as Independent Variables (IVs). The internal challenges include time, attitudes, skills and competences as well as teachers' qualification. The external challenges refer to trainings on ICT, internet coverage, accessibility, technical support and also societal view and school view on the use of ICT. Teachers' perception in this study is known as the moderating variable as it indirectly influences the teachers' willingness to use ICT in classroom. Study has indicated that teachers who have negative perception on ICT implementation normally do not fully engage themselves to use ICT in teaching (Sabzian \& Gilakjani, 2013). Teachers' perception might also indirectly influence the effectiveness of using ICT in education (Aslan \& Zhu, 2016). This study aimed to determine whether gender and teaching experience influence teachers' perception on the ICT integration in schools. A study by Buabeng-Andoh Charles (2012) showed that teachers' perception might be influenced by their personal characteristics.

\section{Methodology}

In this study, quantitative method was used to collect data. A total of 180 questionnaires with 5 point likert-scales ranging from "Strongly Disagree" to "Strongly Agree" were randomly distributed to 12 CIHS in West Malaysia. Due to time constraints and financial limitations, this study did not include CIHS English teachers in East Malaysia.

The questionnaires in this study were adapted from two past studies. For the perception part, the questions were adapted from a past study by Qasem and Viswanathappa (2016) which had focused on teacher's perception on ICT integration through blended learning while another past study by Salehi and Salehi (2012) was adapted to investigate the main challenges that teachers faced on ICT integration in schools.

Statistical Package for the Social Sciences (SPSS) version 24 was used to analyse the results. T-test was used to compare male and female teachers' perception on the ICT integration in schools while the one way ANOVA test was used to analyse how teachers' teaching experience influence their perception to use ICT in education.

\subsection{Pilot Test}

Twenty five CIHS English teachers from West Malaysia were randomly selected for the pilot study before the actual questionnaire was conducted to check for reliability of the data. The results for both perception and challenges were shown as below: 
Table 1 . Pilot study reliability test- perception

Table 2. Pilot study reliability result- challenges

\begin{tabular}{clr|r}
\multicolumn{3}{c}{ Case Processing Summary } \\
& & $\mathrm{N}$ & \multicolumn{1}{c}{$\%$} \\
\hline \multirow{2}{*}{ Cases } & Valid & 25 & 100.0 \\
\cline { 2 - 4 } & Excluded $^{\text {a }}$ & 0 & .0 \\
\cline { 2 - 4 } & Total $^{*}$ & 25 & 100.0 \\
\hline
\end{tabular}

\begin{tabular}{|c|c|}
\hline \multicolumn{2}{|c|}{ Reliability Statistics } \\
\hline Cronbach's & \\
\hline Alpha & $\mathrm{N}$ of Items \\
\hline .896 & 10 \\
\hline
\end{tabular}

Tables 1 and 2 above showed the reliability results on teachers' perception and challenges on ICT integration in school. The Cronbach's Alpha in both categories were more than 0.7 and this showed that the questionnaire used in this study was reliable and suitable for the targeted respondents. A post study reliability test was also carried out and it showed a consistent result of more than 0.7 .

\section{Results and Discussion}

In this study, the questionnaires are divided into three parts. Part A is the respondents' demographic background and their skills and competences on the use of ICT. Part B investigates the English teachers' perception on ICT. Part C looks into the challenges on ICT integration in schools. All the results were analysed by using descriptive analysis and SPSS version 24 for T-test and One Way ANOVA test. 


\subsection{Respondents' Demographic}

Table 3. Respondents' demographic results

\begin{tabular}{lll}
\hline Factors & Frequency & Percentage (\%) \\
\hline Gender & & \\
Male & 40 & 22.2 \\
Female & 140 & 77.8 \\
Total & 180 & 100.0 \\
\hline Teaching Experiences & & \\
< Y Year & 22 & 12.2 \\
1-5 Years & 79 & 43.9 \\
6-10 Years & 41 & 22.8 \\
>10 Years & 38 & 21.1 \\
Total & 180 & 100.0 \\
\hline Qualification & & \\
Diploma & 20 & 11.1 \\
Degree & 134 & 74.4 \\
Master & 26 & 14.4 \\
PHD & 0 & 0 \\
Total & 180 & 100.0 \\
\hline School Sizes & & \\
Large & 135 & 75.0 \\
Medium & 41 & 22.8 \\
Small & 4 & 2.2 \\
Total & 180 & 100.0 \\
\hline Skills And Competences (Multiple Choice) & & \\
Microsoft Word & 176 & 97.7 \\
Microsoft Excel & 140 & 77.7 \\
Power Point & 165 & 91.6 \\
Internet & 169 & 93.8 \\
Email & 161 & 89.4 \\
Total no. of respondents & 180 & NA \\
\hline
\end{tabular}

In this study, $77.8 \%$ respondents were female teachers. Among all 180 respondents, majority of them (43.9\%) have one to five years teaching experiences. $75 \%$ respondents came from large size schools due to their stronger financial ability to provide ICT tools in teaching. Also, there was no $\mathrm{PhD}$ holders among the respondents, $74.4 \%$ of them were degree holders. Lastly, majority of the English teachers in CIHS know how to use Microsoft Word, Power Point, Internet and Email.

\subsection{Teachers' Perception on ICT Integration in Schools}

Based on the results shown in table 6 (appendix A), more than two-third of the respondents had positive perception on ICT integration in schools. They believed that online resources were easier to use and were quite useful for the subjects they teach. A past study also found that teachers were more motivated to teach their students in classroom as ICT provided sufficient information and materials online (Ziden et al., 2011). A study by Prasad, Lalitha and Srikar (2015) concluded that ICT had changed the way of learning from teacher-centred to student centred. More than half of the English teachers agreed that students gained better understanding on the subject while using online software, pictures and applications and students engaged themselves more in the lessons and improved on their quality of learning. A similar study also pointed out that students had obtained better results in their studies and this would help to support their future employability (Dang, 2011). More than two-third of the respondents agreed that ICT had made their work more effective when they were able to search, choose and evaluate teaching materials from different websites. The results revealed that teachers' perception on ICT was significantly influenced by their skills and competences. A past study has indicated that if teachers had the basic ICT skills and abilities, it would encourage them to adopt ICT tools during their lessons (Nang, 2013). The results from this study showed that majority of the English teachers know how to use ICT tools and they often helped other teachers to use the technology. This study 
has found that a majority of the English teachers in CIHS from West Malaysia have positive perception towards ICT. They opined that ICT was not a frustrating experience when they used it in teaching and learning purposes. A minority of the English teachers who held negative perception felt that the trainings offered to them were not enough. Although in the overall, most teachers have positive perception on ICT integration, there were inevitably some major challenges that had hindered them to use ICT.

\subsection{T-Test on Gender and Perception on ICT Integration in Schools}

Table 4. Independent T-Test results

Group Statistics

\begin{tabular}{|r|l|r|r|r|r|}
\hline & Gender & \multicolumn{1}{|c|}{$\mathrm{N}$} & \multicolumn{1}{c|}{ Mean } & Std. Deviation & Std. Error Mean \\
\hline Perception & Male & 40 & 3.6540 & .35299 & .05581 \\
& Female & 140 & 3.6383 & .37593 & .03177 \\
\hline
\end{tabular}

ง

Independent Samples Test

\begin{tabular}{|c|c|c|c|c|c|c|c|c|c|c|}
\hline & \multicolumn{2}{|c|}{$\begin{array}{c}\text { Leyene's } \\
\text { Test for } \\
\text { Equality of } \\
\text { Variances }\end{array}$} & \multicolumn{7}{|c|}{ t-test for Equality of Means } \\
\hline & & \multirow[b]{2}{*}{$\mathrm{F}$} & \multirow[b]{2}{*}{ Sig. } & \multirow[b]{2}{*}{$\mathrm{t}$} & \multirow[b]{2}{*}{ df } & \multirow{2}{*}{$\begin{array}{l}\text { Sig. } \\
(2- \\
\text { tailed })\end{array}$} & \multirow{2}{*}{$\begin{array}{c}\text { Mean } \\
\text { Difference } \\
\end{array}$} & \multirow{2}{*}{$\begin{array}{l}\text { Std. Error } \\
\text { Difference }\end{array}$} & \multicolumn{2}{|c|}{$\begin{array}{l}95 \% \text { Confidence } \\
\text { Interval of the } \\
\text { Difference }\end{array}$} \\
\hline & & & & & & & & & Lower & Upper \\
\hline Perception & $\begin{array}{l}\text { Equal variances } \\
\text { assumed }\end{array}$ & .084 & .773 & .236 & 178 & .814 & .01571 & .06652 & .11555 & .14698 \\
\hline & $\begin{array}{l}\text { Equal variances } \\
\text { not assumed }\end{array}$ & & & .245 & 66.416 & .807 & .01571 & .06422 & .11249 & .14392 \\
\hline
\end{tabular}

In this study, $77.8 \%$ respondents were female compare to only $22.2 \%$ male respondents. However, the results of independent sample t-test showed that there was no significant gender differences in teachers' perception on the use of ICT in Malaysian education, $\mathrm{t}(178)=0.236, \mathrm{p}=0.814$. A similar past study also concluded that male and female teachers hold the same perception on the implementation of ICT in schools (Muslem, Yusuf \& Juliana, 2018).

4.4 One Way ANOVA Test on Teaching Experience and Perception on ICT Integration in Schools

Table 5. One way ANOVA results

Descriptive

\begin{tabular}{|c|c|c|c|c|c|c|c|c|}
\hline & \multirow[b]{2}{*}{$\mathrm{N}$} & \multirow[b]{2}{*}{ Mean } & \multirow[b]{2}{*}{$\begin{array}{c}\text { Std. } \\
\text { Deviation }\end{array}$} & \multirow[b]{2}{*}{ Std. Error } & \multicolumn{2}{|c|}{$\begin{array}{l}95 \% \text { Confidence Interval } \\
\text { for Mean }\end{array}$} & \multirow[b]{2}{*}{ Minimum } & \multirow[b]{2}{*}{ Maximum } \\
\hline & & & & & $\begin{array}{l}\text { Lower } \\
\text { Bound }\end{array}$ & $\begin{array}{l}\text { Upper } \\
\text { Bound }\end{array}$ & & \\
\hline Less than one year & 22 & 3.6655 & .35575 & .07585 & 3.5077 & 3.8232 & 2.80 & 4.36 \\
\hline 1 to 5 years & 79 & 3.6729 & .35349 & .03977 & 3.5937 & 3.7521 & 2.76 & 4.84 \\
\hline 6 to 10 years & 41 & 3.6741 & .37604 & .05873 & 3.5555 & 3.7928 & 2.48 & 4.40 \\
\hline More than 10 years & 38 & 3.5284 & .39698 & .06440 & 3.3979 & 3.6589 & 2.72 & 4.28 \\
\hline Total & 180 & 3.6418 & .37005 & .02758 & 3.5874 & 3.6962 & 2.48 & 4.84 \\
\hline
\end{tabular}




\begin{tabular}{l} 
ANOVA \\
perception \\
\hline
\end{tabular}

An analysis of variance showed that overall, teachers' teaching experience on the perception on ICT integration in schools had no significant differences, $\mathrm{F}(3,176)=1.523, \mathrm{p}=.210$. It means that teachers' perception on the use of ICT would not be affected by their teaching experience. A latest past study also found that there was no significant differences on teachers' perception and their teaching experience (Muslem, Yusuf \& Juliana, 2018). Nevertheless, another past study by Basargekar \& Singhavi (2017) had a different finding that those teachers with more teaching experiences felt unsure when they use new technologies to teach and therefore, might cause them to have negative perception on ICT.

\subsection{Challenges Faced by Teachers on ICT Integration in Schools}

Table 7 in appendix B showed the teachers' challenges on ICT integration in schools. The major challenges faced by English teachers in CIHS in West Malaysia included insufficient trainings provided, lack of time to learn and use ICT during lessons, poor internet coverage and inadequate technical support by the school management. A past study revealed that teachers needed to complete all their lessons within an academic year and therefore, they could not have sufficient time to use ICT in their lessons (Kumutha \& Hamidah, 2014). Teachers felt that it was not necessary to use ICT due to their lack of knowledge on technologies. A study by Kumutha and Hamidah (2014) showed that if teachers didn't attend professional trainings related to ICT, they tended to lose their confidence to use ICT in their lessons. Furthermore, a stable internet connection helped teachers to use ICT in classroom easier. A past study by Gebremendhin and Fenta in 2015 mentioned that teachers were unable to use ICT during their lessons due to poor internet connection. About half of the respondents agreed that the technical support from school management was rather inadequate. A study by Nang (2013) stated that teachers felt unsure to use ICT if the school management didn't provide adequate technical support and regular maintenance. Other challenges such as colleagues' negative perception, societal view and teachers' qualification did not really influence teachers' use of ICT in schools. Only a minority of the respondents felt that lower qualification discouraged them to use ICT in their lessons.

\section{Conclusion and Recommendation}

Past studies related to this topic have been carried out by many researchers, particularly on the effectiveness of ICT as it helped to improve the way of teaching and learning (Khan, Hossain, Hasan \& Clement, 2012). This study aimed to find out the perception and challenges on ICT integration among English teachers in CIHS. The questionnaire results indicated that more than two-third of the English teachers had positive perception towards ICT while only one-third preferred the conventional way of teaching. A past study has indicated that teachers' attitude is the key factor to successfully integrate ICT in education (Hue \& Jalil, 2013). Another past study also concluded that teachers' perception influenced their willingness to use ICT tools in teaching (Gebremedhin \& Fenta, 2015). Other than that, this study has also identified the main challenges faced by English teachers while using ICT, including lack of professional trainings, lack of support by school management, lack of time for preparation of lessons as well as poor internet connection. In conclusion, the result in this study has revealed that when teachers have positive perceptions on ICT integration, it would ultimately promote and enhance the use of ICT in schools.

Based on the results in this study, it is strongly recommended that teachers should be provided with more ICT trainings to enhance their effectiveness and gaining the advantages of teaching and learning using ICT (Ziden et al., 2011). A study by Fu (2013) has concluded that the use of ICT for teachers to prepare lessons have changed their actions and purposes in teaching. For the same reasons, school management should provide professional ICT training to teachers to improve their way of teaching (Bhasin, 2012). To overcome the problem of little access to ICT which has hindered teachers' willingness to use ICT, school managements should ensure that adequate infrastructures and facilities are provided to teachers and students (Bhasin, 2012). The existing facilities should be checked and updated regularly to ensure that they are able to run smoothly (Bhasin, 2012). These results are significant to the educators, researchers and school management to help develop useful guidelines to assist the teachers to overcome the challenges while using ICT in the teaching and learning process. For more in depth information, the researcher suggests that interview sessions should be included in future studies on the integration of ICT in schools so as to 
provide more comprehensive solutions to overcome the challenges faced by teachers while using ICT in teaching. It is also recommended to include those English teachers in East Malaysia in future studies in order to explore additional information on the implementation of ICT in Malaysia education.

\section{References}

Aktaruzzaman, M., Shamim, R.H., \& Clement, C. (2011). Trends and issues to integrate ICT in teaching learning for the future world of education. International Journal of Engineering \& Technology, 11(3), 114-119.

Aslan, A., \& Zhu, C. (2016). Influencing factors and integration of ICT into teaching practices of pre-service and starting teachers. International Journal of Research in Education and Science (IJRES), 2(2), 359-370. https://doi.org/10.21890/ijres.81048

Baker, J., \& Gossman, P. (2013). The learning impact of a Virtual Learning Environment: Students' view. Teacher Education Advancement Network Journal, 5(2), 19-38. Retrieved from http://insight.cumbria.ac.uk/id/eprint/1455/1/146-574-1-PB.pdf

Basargekar, P., \& Singhavi, C. (2017). Factors affecting teachers' perceived proficiency in using ICT in the classroom. IAFOR Journal of Education, 5(2), 67-84. https://doi.org/10.22492/ije.5.2.03

Bhasin, B. (2012). Integration of Information and Communication Technologies in enhancing teaching and learning. Contemporary Educational Technology, 3(2), 130-140. Retrieved from http://cedtech.net/articles/32/324.pdf

Buabeng-Andoh, C. (2012). Factors influencing teachers' adoption and integration of information and communication technology into teaching: A review of the literature. International Journal of Education and Development Using Information and Communication Technology (IJEDICT), 8(1), 136-155. Retrieved from http://files.eric.ed.gov/fulltext/EJ1084227.pdf

Dang, X.T. (2011). Proceedings from International Conference: ICT for Language Learning $4^{\text {th }}$ edition. Factors influencing teacher's use of ICT in language teaching: A case study of Hanoi University Vietnam. Retrieved from https://pdfs.semanticscholar.org/87d4/be7ae8e8e34d563422f18d7dc283fc6fcfbe.pdf

Fu, J.S. (2013). ICT in education: A critical literature review and its implications. International Journal of Education and Development using Information and Communication Technology (IJEDICT), 9(1), 112-125.

Gebremedhin, M.A., \& Fenta, A.A. (2015). Assessing Teachers' Perception on Integrating ICT in Teaching-Learning Process: The Case of Adwa College. Journal of Education and Practice, 6(4), 114-124. Retrieved from https://files.eric.ed.gov/fulltext/EJ1083759.pdf

Ghavifekr, S., \& Ibrahim, M.S. (2015). Effectiveness of ICT integration in Malaysian schools: A quantitative analysis. International Research Journal for Quality in Education, 2(8).

Ghavifekr, S., Ahmad, Z.A.R., Muhammad, F.A.G., Ng, Y.R., Yao, M., \& Zhang, T. (2014). ICT integration in education: Incorporation of teaching \& learning improvement. The Malaysian Online Journal of Educational Technology, 2(2), 24-45.

Gryzelius, J. (2015). ICT in classroom learning: Exploring the discrepancies between ideal conditions and current Malaysian policy. Policy Ideas, 18, 1-14.

Hiew, W. (2012). English Language teaching and learning issues in Malaysia: Learners' perceptions via Facebook dialogue journal. International Refereed Research Journal, 3(1). Retrieved from http://www.researchersworld.com/vol3/Paper_02.pdf

Hue, L., \& Jalil, H.A. (2013). Attitudes towards ICT integration into curriculum and usage among University Lecturers in Vietnam. International Journal of Instruction, 6(2), 53-66. Retrieved from https://files.eric.ed.gov/fulltext/EJ1085366.pdf

Jayanthi, N.S., \& Kumar, R.V. (2016). Use of ICT in English Language teaching and learning. Journal of English Language and Literature (JOELL), 3(2). Retrieved from http://joell.in/wp-content/uploads/2016/03/34-38Use-of-ICT-in-English-Language-Teaching.pdf

Khan, M., Hossain, S., Hasan, M., \& Clement, C.K. (2012). Barriers to the introduction of ICT into education in developing countries: The example of Bangladesh. International Journal of Instruction, 5(2), 61-80.

Kumutha, R., \& Hamidah, Y. (2014). Barriers teachers face in integrating ICT during English lessons: A case study. The Malaysian Online Journal of Educational Technology, 2(3). Retrieved from https://files.eric.ed.gov/fulltext/EJ1086402.pdf 
Low, M.J. (2015). Chinese private schools as a viable route to secondary education in Malaysia: A case study. Malaysian Journal of Chinese Studies, 4(2), 45-59. Retrieved from https://www.newera.edu.my/files/publication/Journal/vol4no2-3.pdf

Md. Shah, P., \& L. Empungan, J. (2015). ESL teachers' attitudes towards using ICT in literature lessons. International Journal of English Language Education, 3(1). https://doi.org/10.5296/ijele.v3i1.7158

Meenakshi. (2013). Importance of ICT in education. IOSR Journal of Research \& Method in Education, 1(4), 03-08. https://doi.org/10.9790/7388-0140308

Ministry of Education Malaysia. (2015). Malaysia Education Blueprint 2015-2025 (Higher Education). Kementerian Pendidikan Malaysia. Retrieved from http://www.mohe.gov.my/index.php/muat-turun/awam/penerbitan/pppm-2015-2025-pt/5-malaysia-education-bl ueprint-2015-2025-higher-education?format=html\&path=awam/penerbitan/pppm-2015-2025-pt

Moussa, A. (2018). Does Agricultural Sector Contribute to the Economic Growth in Case of Republic of Benin?. Journal of Social Economics Research, 5(2), 85-93. https://doi.org/10.18488/journal.35.2018.52.85.93

Mujtaba, M., \& Jamal, S. (2018). Enhancing Work Climate to Improve the Perceived Performance Leading to Talent Retention-A Study of Pakistani Service Sector. International Journal of Social Sciences Perspectives, 3(1), 21-33. https://doi.org/10.33094/7.2017.2018.31.21.33

Murshed, M. (2018). International Tourism Demand in Bangladesh: An ARDL Bounds Test Approach. Journal of Tourism Management Research, 5(1), 50-67. https://doi.org/10.18488/journal.31.2018.51.50.67

Musa, A., Abdullahi, D., \& Baba, Y. T. (2017). Youth Unemployment and Violent Mobilization in Kebbi State. International Journal of Social and Administrative Sciences, 2(1), 1-7. https://doi.org/10.18488/journal.136.2017.21.1.7

Muslem, A., Yusuf, Y., \& Juliana, R. (2018). Perceptions and barriers to ICT use among English teacher in Indonesia. Teaching English with Technology, 18(1), 3-23.

Mwanja, S. K., Evusa, Z., \& Ndirangu, A. W. (2018). Influence of Corporate Social Responsibility on Firm Performance among Companies Listed on the Nairobi Securities Exchange. International Journal of Applied Economics, Finance and Accounting, 3(2), 56-63. https://doi.org/10.33094/8.2017.2018.32.56.63

Nang, A. (2013). Opportunities and challenges for use and integration of information communication technology in management of public secondary schools in Bungoma South District, Kenya. International Journal of Science and Research (IJSR), 2(8), 215-221.

Prasad, C.V.V.S.N.V., Lalitha, P., \& Srikar, P.V.N. (2015). Barriers to the use of Information and Communication Technology (ICT) in secondary schools: Teacher's perspective. Journal of Management Research, 7(2), 190-208. https://doi.org/10.5296/jmr.v7i2.6935

Qasem, A.A.A., \& Viswanathappa, G. (2016). Teacher perceptions towards ICT integration: Professional development through blended learning. Journal of Information Technology Education: Research, 15, 561-575. https://doi.org/10.28945/3562

Raman, A., \& Halim Mohamed, A. (2013). Issues of ICT usage among Malaysian Secondary School English Teachers. English Language Teaching, 6(9), 74-82. https://doi.org/10.5539/elt.v6n9p74

Sabzian, F., \& Gilakjani, A.P. (2013). Teachers' attitudes about computer technology training professional development, integration, experience, anxiety and literacy in English language teaching and learning. International Journal of Applied Science and Technology, 3(1), 67-75. Retrieved from http://www.ijastnet.com/journals/Vol_3_No_1_January_2013/9.pdf

Salehi, H., \& Salehi, Z. (2012). Challenges for using ICT in education: Teachers' insights. International Journal of e-Education, e-Business, e-Management and e-Learning, 2(1), 40-43.

Tan, Y.S., \& Teoh, H.S. (2014). The development of Chinese education in Malaysia, 1952-1975: political collaboration between the Malaysian Chinese Association and the Chinese educationists. History of Education. Journal of the History of Education Society. https://doi.org/10.1080/0046760X.2014.959073

Tian, C., \& Correos, C. C. (2014). Teachers' ICT Literacy and Utilization in English Language Teaching. 'ICT \& Innovations in Education' International Electronic Journal, 2(1), 1-25.

Yunus, M.M., Salehi, H., \& Chenzi, C. (2012). Integrating social networking tools into ESL writing classroom: 
Strengths and weaknesses. English Language Teaching, 5(8), 42-48. https://doi.org/10.5539/elt.v5n8p42

Ziden, A.A., Issham, I., Spian, R., \& Kumutha, K. (2011). The effects of ICT use in teaching and learning on students' achievement in Science subject in a primary school in Malaysia. Malaysia Journal of Distance Education, 13(2), 19-32.

\section{Appendixes}

\section{Appendix A}

Table 6. Teachers' perception on ICT integration in schools

\begin{tabular}{|c|c|c|c|c|c|c|}
\hline No. & Questions & 1 & 2 & 3 & 4 & 5 \\
\hline 1. & $\begin{array}{l}\text { It is easy for me to manage a course by using } \\
\text { internet applications. }\end{array}$ & $\begin{array}{c}0 \\
(0 \%)\end{array}$ & $\begin{array}{c}13 \\
(7.2 \%)\end{array}$ & $\begin{array}{c}36 \\
(20.0 \%)\end{array}$ & $\begin{array}{c}91 \\
(50.6 \%)\end{array}$ & $\begin{array}{c}40 \\
(22.2 \%)\end{array}$ \\
\hline 2. & $\begin{array}{l}\text { I think that the internet applications and resources } \\
\text { are available for my subjects. }\end{array}$ & $0(0 \%)$ & $\begin{array}{c}12 \\
(6.7 \%)\end{array}$ & $\begin{array}{c}23 \\
(12.8 \%)\end{array}$ & $\begin{array}{c}100 \\
(55.6 \%)\end{array}$ & $\begin{array}{c}45 \\
(25 \%)\end{array}$ \\
\hline 3. & I am aware of the opportunities that computer offer. & $1(0.6 \%)$ & $\begin{array}{c}4 \\
(2.2 \%)\end{array}$ & $\begin{array}{c}25 \\
(13.9 \%)\end{array}$ & $\begin{array}{c}110 \\
(61.1 \%)\end{array}$ & $\begin{array}{c}40 \\
(22.2 \%)\end{array}$ \\
\hline 4. & $\begin{array}{l}\text { I believe that the communication tools (e.g., mail, } \\
\text { forum, Blog, and chat) will make communication with } \\
\text { my peers and students easier. }\end{array}$ & $\begin{array}{c}0 \\
(0 \%)\end{array}$ & $\begin{array}{c}9 \\
(5 \%)\end{array}$ & $\begin{array}{c}31 \\
(17.2 \%)\end{array}$ & $\begin{array}{c}105 \\
(58.3 \%)\end{array}$ & $\begin{array}{c}35 \\
(19.4 \%)\end{array}$ \\
\hline 5. & $\begin{array}{l}\text { I can evaluate and select new information resources } \\
\text { and technological innovations based on their }\end{array}$ & $\begin{array}{c}0 \\
(0 \%)\end{array}$ & $\begin{array}{c}7 \\
(3.9 \%)\end{array}$ & $\begin{array}{c}52 \\
(28.9 \%)\end{array}$ & $\begin{array}{c}91 \\
(50.6 \%)\end{array}$ & $\begin{array}{c}30 \\
(16.7 \%)\end{array}$ \\
\hline
\end{tabular}

\begin{tabular}{|c|c|c|c|c|c|c|}
\hline 6. & $\begin{array}{l}\text { I think that I can use ICT for instructional design and } \\
\text { class room activities more effectively day by day. }\end{array}$ & $0(0 \%)$ & $\begin{array}{c}7 \\
(3.9 \%)\end{array}$ & $\begin{array}{c}41 \\
(22.8 \%)\end{array}$ & $\begin{array}{c}99 \\
(55 \%)\end{array}$ & $\begin{array}{c}33 \\
(18.3 \%)\end{array}$ \\
\hline 7. & $\begin{array}{l}\text { I can discuss diversity issues related to electronic } \\
\text { media. }\end{array}$ & $2(1.1 \%)$ & $\begin{array}{c}11 \\
(6.1 \%)\end{array}$ & $\begin{array}{c}76 \\
(42.2 \%)\end{array}$ & $\begin{array}{c}68 \\
(37.8 \%)\end{array}$ & $\begin{array}{c}23 \\
(12.8 \%)\end{array}$ \\
\hline 8. & $\begin{array}{l}\text { I think that ICT integration includes supporting } \\
\text { various student learning styles and to personalize } \\
\text { learning. }\end{array}$ & $\begin{array}{c}0 \\
(0 \%)\end{array}$ & $\begin{array}{c}6 \\
(3.3 \%)\end{array}$ & $\begin{array}{c}33 \\
(18.3 \%)\end{array}$ & $\begin{array}{c}110 \\
(61.1 \%)\end{array}$ & $\begin{array}{c}31 \\
(17.2 \%)\end{array}$ \\
\hline 9. & $\begin{array}{l}\text { I believe that using content-specific tools (e.g., } \\
\text { software, simulation, graphing calculators, Web }\end{array}$ & $\begin{array}{c}0 \\
(0 \%)\end{array}$ & $\begin{array}{c}4 \\
(2.2 \%)\end{array}$ & $\begin{array}{c}38 \\
(21.1 \%)\end{array}$ & $\begin{array}{c}108 \\
(60 \%)\end{array}$ & $\begin{array}{c}30 \\
(16.7 \%)\end{array}$ \\
\hline
\end{tabular}

\begin{tabular}{|c|c|c|c|c|c|c|}
\hline 10. & $\begin{array}{l}\text { I think that using ICT in learning increases the } \\
\text { interest of students toward courses. }\end{array}$ & $\begin{array}{c}0 \\
(0 \%)\end{array}$ & $\begin{array}{c}2 \\
(1.1 \%)\end{array}$ & $\begin{array}{c}28 \\
(15.6 \%)\end{array}$ & $\begin{array}{c}107 \\
(59.4 \%)\end{array}$ & $\begin{array}{c}43 \\
(23.9 \%)\end{array}$ \\
\hline 11. & $\begin{array}{l}\text { I think that using ICT for instructional design } \\
\text { increases the quality of courses. }\end{array}$ & $\begin{array}{c}0 \\
(0 \%)\end{array}$ & $\begin{array}{c}6 \\
(3.3 \%)\end{array}$ & $\begin{array}{c}54 \\
(30 \%)\end{array}$ & $\begin{array}{c}93 \\
(51.7 \%)\end{array}$ & $\begin{array}{c}27 \\
(15 \%)\end{array}$ \\
\hline 12. & $\begin{array}{l}\text { I think that ICT usage makes it easier to prepare } \\
\text { course materials. }\end{array}$ & $\begin{array}{c}0 \\
(0 \%)\end{array}$ & $\begin{array}{c}11 \\
(6.1 \%)\end{array}$ & $\begin{array}{c}28 \\
(15.6 \%)\end{array}$ & $\begin{array}{c}114 \\
(63.3 \%)\end{array}$ & $\begin{array}{c}27 \\
(15 \%)\end{array}$ \\
\hline 13. & $\begin{array}{l}\text { It is hard for me to explain the use of computer } \\
\text { applications to my students. }\end{array}$ & $\begin{array}{c}16 \\
(8.9 \%)\end{array}$ & $\begin{array}{c}76 \\
(42.2 \%)\end{array}$ & $\begin{array}{c}45 \\
(25 \%)\end{array}$ & $\begin{array}{c}34 \\
(18.9 \%)\end{array}$ & $\begin{array}{c}9 \\
(5 \%)\end{array}$ \\
\hline 14. & $\begin{array}{l}\text { I think that there is inadequacy of the courses of } \\
\text { technology offered to teachers. }\end{array}$ & $\begin{array}{c}6 \\
(3.3 \%)\end{array}$ & $\begin{array}{c}27 \\
(15 \%)\end{array}$ & $\begin{array}{c}57 \\
(31.7 \%)\end{array}$ & $\begin{array}{c}76 \\
(42.2 \%)\end{array}$ & $\begin{array}{c}14 \\
(7.8 \%)\end{array}$ \\
\hline 15. & I think technology makes effective use of class ti & 2 & 9 & $\begin{array}{c}38 \\
(21.1 \%)\end{array}$ & $\begin{array}{c}108 \\
(60 \%)\end{array}$ & $\begin{array}{c}23 \\
(12.8 \%)\end{array}$ \\
\hline
\end{tabular}




\begin{tabular}{|c|c|c|c|c|c|c|}
\hline & & $(1.1 \%)$ & $(5 \%)$ & & & \\
\hline 16. & $\begin{array}{l}\text { I think I can use a variety of media and formats, } \\
\text { including telecommunications, to collaborate, publish, } \\
\text { and interact with peers, experts, and other audiences. }\end{array}$ & $\begin{array}{c}0 \\
(0 \%)\end{array}$ & $\begin{array}{c}11 \\
(6.1 \%)\end{array}$ & $\begin{array}{c}40 \\
(22.2 \%)\end{array}$ & $\begin{array}{c}108 \\
(60 \%)\end{array}$ & $\begin{array}{c}21 \\
(11.7 \%)\end{array}$ \\
\hline 17. & $\begin{array}{l}\text { I think that using technology makes it easier to } \\
\text { locate, evaluate, and collect information from a } \\
\text { variety of sources. }\end{array}$ & $\begin{array}{c}0 \\
(0 \%)\end{array}$ & $\begin{array}{c}4 \\
(2.2 \%)\end{array}$ & $\begin{array}{c}25 \\
(13.9 \%)\end{array}$ & $\begin{array}{c}121 \\
(67.2 \%)\end{array}$ & $\begin{array}{c}30 \\
(16.7 \%)\end{array}$ \\
\hline 18. & $\begin{array}{l}\text { I think that the use of technology tools and } \\
\text { information resources for increased productivity, } \\
\text { promote creativity, and facilitate academic learning. }\end{array}$ & $\begin{array}{c}0 \\
(0 \%)\end{array}$ & $\begin{array}{c}1 \\
(0.6 \%)\end{array}$ & $\begin{array}{c}32 \\
(17.8 \%)\end{array}$ & $\begin{array}{c}115 \\
(63.9 \%)\end{array}$ & $\begin{array}{c}32 \\
(17.8 \%)\end{array}$ \\
\hline 19. & $\begin{array}{l}\text { I think that there is lack of interest of teachers in } \\
\text { technology usage. }\end{array}$ & $\begin{array}{c}5 \\
(2.8 \%)\end{array}$ & $\begin{array}{c}38 \\
(21.1 \%)\end{array}$ & $\begin{array}{c}76 \\
(42.2 \%)\end{array}$ & $\begin{array}{c}50 \\
(27.8 \%)\end{array}$ & $\begin{array}{c}11 \\
(6.1 \%)\end{array}$ \\
\hline 20. & $\begin{array}{l}\text { I could use ICT if I had online support on instructional } \\
\text { technology design. }\end{array}$ & $\begin{array}{c}1 \\
(0.6 \%)\end{array}$ & $\begin{array}{c}7 \\
(3.9 \%)\end{array}$ & $\begin{array}{c}33 \\
(18.3 \%)\end{array}$ & $\begin{array}{c}121 \\
(67.2 \%)\end{array}$ & $\begin{array}{c}18 \\
(10 \%)\end{array}$ \\
\hline 21. & $\begin{array}{l}\text { I believe that acquiring the skills to ICT integration } \\
\text { in teaching will be easy to me. }\end{array}$ & $\begin{array}{c}2 \\
(1.1 \%)\end{array}$ & $\begin{array}{c}8 \\
(4.4 \%)\end{array}$ & $\begin{array}{c}30 \\
(16.7 \%)\end{array}$ & $\begin{array}{c}117 \\
(65 \%)\end{array}$ & $\begin{array}{c}23 \\
(12.8 \%)\end{array}$ \\
\hline 22. & $\begin{array}{l}\text { I believe that using ICT will be a frustrating } \\
\text { experience. }\end{array}$ & $\begin{array}{c}30 \\
(16.7 \%)\end{array}$ & $\begin{array}{c}78 \\
(43.3 \%)\end{array}$ & $\begin{array}{c}38 \\
(21.1 \%)\end{array}$ & $\begin{array}{c}31 \\
(17.2 \%)\end{array}$ & $\begin{array}{c}3 \\
(1.7 \%)\end{array}$ \\
\hline 23. & $\begin{array}{l}\text { I believe that I can improve my English language } \\
\text { skills using the benefits of ICT. }\end{array}$ & $\begin{array}{c}0 \\
(0 \%)\end{array}$ & $\begin{array}{c}5 \\
(2.8 \%)\end{array}$ & $\begin{array}{c}39 \\
(21.7 \%)\end{array}$ & $\begin{array}{c}101 \\
(56.1 \%)\end{array}$ & $\begin{array}{c}35 \\
(19.4 \%)\end{array}$ \\
\hline 24. & $\begin{array}{l}\text { My peers often ask me for advice or information on } \\
\text { ICT integration in instructional design. }\end{array}$ & $\begin{array}{c}6 \\
(3.3 \%)\end{array}$ & $\begin{array}{c}44 \\
(24.4 \%)\end{array}$ & $\begin{array}{c}60 \\
(33.3 \%)\end{array}$ & $\begin{array}{c}64 \\
(35.6 \%)\end{array}$ & $\begin{array}{c}6 \\
(3.3 \%)\end{array}$ \\
\hline 25. & $\begin{array}{l}\text { I think that ICT is incompatible with all the courses I } \\
\text { teach. }\end{array}$ & $\begin{array}{c}20 \\
(11.1 \%)\end{array}$ & $\begin{array}{c}66 \\
(36.7 \%)\end{array}$ & $\begin{array}{c}61 \\
(33.9 \%)\end{array}$ & $\begin{array}{c}30 \\
(16.7 \%)\end{array}$ & $\begin{array}{c}3 \\
(1.7 \%)\end{array}$ \\
\hline
\end{tabular}

\section{Appendix B}

Table 7. Challenges faced by teachers on ICT integration in schools

\begin{tabular}{|c|c|c|c|c|c|c|}
\hline No. & Questions & 1 & 2 & 3 & 4 & 5 \\
\hline 1. & Shortage of class time hinders me to use ICT. & $\begin{array}{c}8 \\
(4.4 \%)\end{array}$ & $\begin{array}{c}42 \\
(23.3 \%)\end{array}$ & $\begin{array}{c}31 \\
(17.2 \%)\end{array}$ & $\begin{array}{c}70 \\
(38.9 \%)\end{array}$ & $\begin{array}{c}29 \\
(16.1 \%)\end{array}$ \\
\hline 2. & $\begin{array}{l}\text { There is no enough training provided for teachers } \\
\text { about the use of ICT in teaching. }\end{array}$ & $\begin{array}{c}3 \\
(1.7 \%)\end{array}$ & $\begin{array}{c}24 \\
(13.3 \%)\end{array}$ & $\begin{array}{c}41 \\
(22.8 \%)\end{array}$ & $\begin{array}{c}90 \\
(50 \%)\end{array}$ & $\begin{array}{c}22 \\
(12.2 \%)\end{array}$ \\
\hline 3. & $\begin{array}{l}\text { The insufficient internet coverage in schools } \\
\text { prevents me to use ICT. }\end{array}$ & $\begin{array}{c}6 \\
(3.3 \%)\end{array}$ & $\begin{array}{c}48 \\
(26.7 \%)\end{array}$ & $\begin{array}{c}23 \\
(12.8 \%)\end{array}$ & $\begin{array}{c}70 \\
(38.9 \%)\end{array}$ & $\begin{array}{c}33 \\
(18.3 \%)\end{array}$ \\
\hline 4. & Little access to ICT prevents me to use ICT & $\begin{array}{c}9 \\
(5 \%)\end{array}$ & $\begin{array}{c}50 \\
(27.8 \%)\end{array}$ & $\begin{array}{c}36 \\
(20 \%)\end{array}$ & $\begin{array}{c}66 \\
(36.7 \%)\end{array}$ & $\begin{array}{c}19 \\
(10.6 \%)\end{array}$ \\
\hline 5. & $\begin{array}{l}\text { Few ICT technical supports at schools discourage } \\
\text { me to use ICT in classroom. }\end{array}$ & $\begin{array}{c}7 \\
(3.9 \%)\end{array}$ & $\begin{array}{c}56 \\
(31.1 \%)\end{array}$ & $\begin{array}{c}30 \\
(16.7 \%)\end{array}$ & $\begin{array}{c}68 \\
(37.8 \%)\end{array}$ & $\begin{array}{c}19 \\
(10.6 \%)\end{array}$ \\
\hline 6. & Society views about ICT discourage me to use ICT. & $\begin{array}{c}19 \\
(10.6 \%)\end{array}$ & $\begin{array}{c}90 \\
(\mathbf{5 0 \%})\end{array}$ & $\begin{array}{c}50 \\
(27.8 \%)\end{array}$ & $\begin{array}{c}18 \\
(10 \%)\end{array}$ & $\begin{array}{c}3 \\
(1.7 \%)\end{array}$ \\
\hline
\end{tabular}




\begin{tabular}{|c|c|c|c|c|c|c|}
\hline 7. & $\begin{array}{l}\text { Colleagues' negative views about ICT hinder me to } \\
\text { use ICT in the class. }\end{array}$ & $\begin{array}{c}18 \\
(10 \%)\end{array}$ & $\begin{array}{c}96 \\
(53.3 \%)\end{array}$ & $\begin{array}{c}41 \\
(22.8 \%)\end{array}$ & $\begin{array}{c}22 \\
(12.2 \%)\end{array}$ & $\begin{array}{c}3 \\
(1.7 \%)\end{array}$ \\
\hline 8. & School views about ICT discourage me to use ICT. & $\begin{array}{c}21 \\
(11.7 \%)\end{array}$ & $\begin{array}{c}72 \\
(40 \%)\end{array}$ & $\begin{array}{c}45 \\
(25 \%)\end{array}$ & $\begin{array}{c}31 \\
(17.2 \%)\end{array}$ & $\begin{array}{c}11 \\
(6.1 \%)\end{array}$ \\
\hline 9. & $\begin{array}{l}\text { Time needed to learn using ICT prevents me to use } \\
\text { ICT. }\end{array}$ & $\begin{array}{c}13 \\
(7.2 \%)\end{array}$ & $\begin{array}{c}70 \\
(38.9 \%)\end{array}$ & $\begin{array}{c}32 \\
(17.8 \%)\end{array}$ & $\begin{array}{c}57 \\
(31.7 \%)\end{array}$ & $\begin{array}{c}8 \\
(4.4 \%)\end{array}$ \\
\hline 10. & $\begin{array}{l}\text { Requirements of qualifications discourage me to } \\
\text { use ICT. }\end{array}$ & $\begin{array}{c}36 \\
(14.4 \%)\end{array}$ & $\begin{array}{c}79 \\
(43.9 \%)\end{array}$ & $\begin{array}{c}41 \\
(22.8 \%)\end{array}$ & $\begin{array}{c}28 \\
(15.6 \%)\end{array}$ & $\begin{array}{c}6 \\
(3.3 \%)\end{array}$ \\
\hline
\end{tabular}

